\title{
Approaches to studying in higher education Portuguese students: a Portuguese version of the approaches and study skills inventory for students
}

\author{
Sandra Cristina A. T. S. Valadas • Fernando R. Gonçalves • \\ Luís M. Faísca
}

(C) Springer Science+Business Media B.V. 2009

\begin{abstract}
This paper examines the validity of the Approaches and Study Skills Inventory for Students - short version (ASSIST; Tait et al. in Improving student learning: Improving students as learners, 1998), to be used with Portuguese undergraduate students. The ASSIST was administrated to 566 students, in order to analyse a Portuguese version of this inventory. Exploratory factor analysis (principal axis factor analysis followed by direct oblimin rotation) reproduced the three main factors that correspond to the original dimensions of the inventory (deep, surface apathetic and strategic approaches to learning). The results are consistent with the background theory on approaches to learning. Additionally, the reliability analysis revealed acceptable internal consistency indexes for the main scales and subscales. This inventory might represent a valuable research tool for the assessment of approaches to learning among Portuguese higher education students.
\end{abstract}

Keywords Approaches to studying · ASSIST · Conceptions of learning · Learning outcomes · Portuguese undergraduate students

S. C. A. T. S. Valadas $(\bowtie) \cdot$ F. R. Gonçalves

CUIE, Faculdade de Ciências Humanas e Sociais, Universidade do Algarve, Campus de Gambelas, 8005-139 Faro, Portugal

e-mail: svaladas@ualg.pt

S. C. A. T. S. Valadas · F. R. Gonçalves

CIECC, Universidade de Aveiro, 3810-193 Aveiro, Portugal

L. M. Faísca

Cognitive Neuroscience Research Group, Departamento de Psicologia, Faculdade de Ciências

Humanas e Sociais, Universidade do Algarve, Faro, Portugal

L. M. Faísca

Instituto de Psicologia Cognitiva, Desenvolvimento Vocacional e Social, FPCE, Universidade de Coimbra, 3001-802 Coimbra, Portugal 


\section{Background and purpose}

Approaches to learning refer to the intentions students have facing a learning situation, as well as the corresponding strategies by which they achieve learning outcomes. The construct of approaches to learning is based on the original investigation of Marton and Säljö (1976a). Marton and Säljö (1976a, b) identified two qualitatively different ways of approaching a reading task of a text: some students tried to understand the text, others attempted to memorize it. The authors used the terms "deep-level processing" and "surface-level processing" to talk about the way students approach particular tasks such as reading a simple academic text.

Individual differences were the base of a tradition concerning the way students perceived their role as learners, learning outcomes and study, in general. Marton and Säljö then asked students how they went about their regular studies, and they made an analogous distinction between a deep approach and a surface approach.

The concepts of deep and surface approaches to learning resulted in the construction of a series of self-response inventories (Biggs 1987b; Entwistle 1979; Entwistle and Ramsden 1983; Lonka and Lindblom-Ylänne 1996; Vermunt 1998), to investigate not only approaches, but other aspects of learning: motivation to study, learning conceptions, and preferred study strategies. The most referenced instruments are: the Approaches to Studying Inventory (ASI; Entwistle and Ramsden 1983), the Revised Approaches to Studying Inventory (RASI; Entwistle and Tait 1994), the Study Process Questionnaire (Biggs 1987a, 1993) and, more recently, the Approaches and Study Skills Inventory for Students (Entwistle 1997a, b; Tait et al. 1998).

The three more recent approaches are: deep approach, surface apathetic approach and strategic approach, and they may reflect different levels of processing.

According to Entwistle and Peterson (2004), motives determined the learning process. In this sense, deep approach was characterised as the interest in different subjects and the intention to understand. On the contrary, surface apathetic approach involved the intention to accomplish the minimum tasks of the discipline. This aspect suggested external interests that lead to routines, memorisation and to the use of learning strategies without reflexion. Concerning strategic approach, students valorise monitoring efficacy when studying (Entwistle et al. 2001) and give a special attention to assessment demands - these aspects refer to metacognitive component and to selfregulation of learning according to Vermunt (1998) and Pintrich and Garcia (1994).

Originally, the motives related to the strategic approach reflected realisation, but the most recent investigations confirm that the intention is the result of a sense of responsibility through himself, the others, or to the society (Meyer 2001). In terms of results, the intention leads to organised study, time management, effort and concentration, and engages selfregulation and learning context.

Although the key-concept of the work of Marton and his colleagues (Marton and Säljö 1976a, b, 1997) referred to approaches to learning, these authors also considered a study approach that they described as the strategic approach (Entwistle and Ramsden 1983).

Entwistle and Ramsden (1983), when investigating the influence of assessment procedures in learning and studying, considered the necessity to introduce this additional category. The underlying motive was to achieve a higher level of performance, through the use of organised methods of study and time management. In the authors opinion it was clear that original interviews misplaced a crucial influence on learning - the one related to assessment-which justified the fact that the additional category of a strategic approach was designed as a study approach and not an approach to learning (Biggs 1987a; Entwistle 
and Ramsden 1983). On the other hand, original research also demonstrated that students have implicit theories concerning the demands of the different courses and disciplines. This statement refers to the different teaching and assessment procedures that can be observed in specific scientific domains (Entwistle and Ramsden 1983; Ramsden 1988). Strategic students seem to develop two focuses of interests: academic content (characteristic of a deep approach) and the demands of the evaluation system (typically strategic; Entwistle 2000).

Despite the fact that the distinction between deep and surface was the product of analyses concerning the meaning of a text, strategic and surface apathetic approaches (Tait and Entwistle 1996) pointed out the way students behave in daily study situations. In this sense, the authors support that we cannot talk about individual differences, but descriptions of relations between the students and the learning tasks that they realise. In our investigation, we adopt Entwistle and Ramsden (1983), Entwistle et al. (2001), and Biggs' (2001) perspectives. According to these authors, approaches to learning are not individual characteristics in a simplistic sense; they result from personal experience and they are constructs influenced by teaching, assessment and learning context. To Entwistle et al. (2001) approaches to learning can be generalised, but they also require specificity considering the way they behave in different situations. In this sense, these constructs are combinations that represent the complexity of the phenomena. Probably the most widely used questionnaire on student learning assessment in higher education (Richardson 2000) is the ASI, developed by Entwistle and Ramsden (1983).

This paper examines the most recent version of the ASI-the Approaches and Study Skills Inventory for Students - short version (ASSIST; Tait et al. 1998). The purpose was to validate a Portuguese version of ASSIST, by attempting to reproduce the original factor structure using exploratory factor analysis procedures.

\section{Methods}

Sample

Data was collected in a public university located in the south of Portugal, with a student population of 2,161 students on the university sub-system. Considering the diversity of courses existing at the University (32), sampling procedure was based on the natural grouping in Faculties. Students that participated in the study attended courses from different areas: Humanities and Social Sciences, Natural, Physical and Technological Sciences.

To preserve heterogeneity, and also for theoretical reasons, we regarded the year and the course attended. Students from 1st and last years of college (in Portugal, before the Bologna process, most of the courses comprised four and 5 years of duration) were included. In this sense a stratified proportional sampling was used, based on the scientific area and year of schooling.

From a total of 626 students, we eliminated 60 for not responding to most of the questions. Since eliminated subjects did not show any statistical association with subsamples defined by school and socio-demographic characteristics (gender, age, scientific area and year of schooling), missing values can be considered randomly distributed within subsamples.

The final sample comprised 566 students (218 males and 348 females), with ages between 18 and 48 years $($ Mean $=22.29 ; \mathrm{SD}=4.29$. Mo $=21$ ). Students were roughly 
equally distributed in the scientific areas: Humanities and Social Sciences (45.76\%), Natural, Physical and Technological Sciences (54.24\%).

To evaluate the representativeness of our sample, the chi-square test for heterogeneity of proportions was used. The result was statistically significant $\left(\chi^{2}=35.23\right.$; g.l. $=4$; $P<0.000$ ), which means that the sample distribution is rather different from the population distribution. In this sense, our sample is not representative of the population. The most significant differences were related to students from Technological and Natural Sciences.

Instrument

ASSIST (Tait et al. 1998) is the last in a line of inventories (ASI and RASI) designed to measure individual differences in approaches to learning in higher education students. The instrument was developed through ASI, including additional subscales related to study aspects, but also to reactions to teaching.

The inventory consists of four sections. The first section (what is learning?) refers to the conceptions of learning described by Marton and Säljö (1976a, b), and further developed by Hattie et al. (1996). This section includes six items that evaluate student conception of the definition of the term "learning"-what learning means to them. Items perform as categories that integrate, in some way, a hierarchy. The first three categories tend to be related with an instrumental approach and can be combined to indicate the conception of learning as reproduction of knowledge (surface). The other three categories are associated with a perspective of learning that involves comprehension and personal development. The second section consists of 52 items that assess study approaches in three different dimensions or scales: deep, strategic and instrumental-this one defined by Tait et al. (1998) as Surface Apathetic. The items consist of statements describing what university students usually do when they learn. Respondents indicate their agreement by setting a mark on a five point scale $(1=$ disagree, $5=$ agree $)$. These approaches to study are the product of Marton and Säljös' work (1976a, b, 1997) on approaches to learning, in articulation with the strategic approach described by Entwistle and Ramsden (1983) and Ramsden and Entwistle (1981). The three main approaches are divided into 13 subscales, related subscales and motives scales, which comprise learning strategies, motivation and intention. Each subscale includes four items, and each approach four or five subscales: deep approach, four subscales (16 items); surface apathetic, also four (16 items) and strategic approach, five subscales (20 items). The first three subscales are most consistently related. The subsequent related subscales and related motive scale are likely to vary in their relationship (Diseth 2001). Entwistle et al. (2000) also referred to the possibility of variation across different samples, and considered that relationships between subscales need to be always confirmed. The related motives are interest in ideas (subII), achieving (subA) and fear of failure (subFF). The third section of ASSIST includes eight items measuring the preferences for different types of learning and teaching. Students are asked to indicate to what extent they like better, or not, different types of lectures, exams, courses and books. Theoretically, the answers to these items reflect two latent factors: support of understanding (deep approach) and transmission of information (surface approach).

A last section refers to academic work already assessed in a scale ranging from 1 (rather badly) to 9 (very well). Student is questioned about his or her academic performance on the basis of his self-perception but also on feedback received from teachers.

Concerning scoring procedures, scores for the 13 subscales correspond to the sum of individual responses to the items (from 1 to 5). Scores for each approach are the sum of the 
scores obtained on the subscales that contribute to the approach. ASSIST application can be individual or collective and lasts from 25 to $45 \mathrm{~min}$.

\section{Procedure}

A standard translation-back translation (Hill and Hill 2000) procedure was used to ensure that the meaning content of each item in the present version was equivalent to the original version of the inventory. Translation to Portuguese language was made by different Portuguese individuals, all with good skills in English language. After comparing and integrating the different versions, a revised translated version was submitted to a backtranslation by a Portuguese individual, with very good skills on both languages (Almeida and Freire 2000). Finished the procedure, and once minor differences in wording had been dealt with, no major incompatibilities in the translations were observed. Portuguese version of the ASSIST maintained the original structure (Appendix).

The ASSIST was distributed to a sample of higher education students of a Portuguese public institution, during the year 2004/2005. After obtaining the necessary authorization from the Heads of the Faculties (five) and the teachers involved, teachers and students were informed of the goals of the study, as well as of the conditions to participate. Data was collected in the context of teaching lessons. Explained the purpose of the research, the inventory was distributed to students, that were instructed to complete it in respect to their general learning tasks and study. Participation was on a voluntary basis and confidentiality of all the information collected was assured. We also guaranteed the dissemination of the results of this investigation. One of the investigators was always present at the application sessions.

\section{Data analysis}

Results presented here only refer to the second section of the inventory (52 items corresponding to 13 subscales and three scales). Items describing conceptions of learning (first section of the inventory) were not used because previous investigations did not confirm their inclusion in the factorial structure theoretically described for ASSIST (Byrne et al. 2004a, b; Diseth 2001; Tait et al. 1998).

As well as in other studies (Byrne et al. 2004b; Diseth 2001; Entwistle et al. 2000; Kreber 2003; Tait et al. 1998) factor analysis was performed at the subscale level and not at the item level, considering that the 13 factors solution suggested by Tait et al. (1998) was not confirmed (Kreber 2003). The subscales included in this analysis were those contributing to the three main factors.

In a preliminary descriptive approach, we calculated several descriptive statistics and the Cronbach's alpha for each scale and subscale of ASSIST. This descriptive analysis was followed by construct validity analysis. Our intent was to verify if the structure of the Portuguese version of ASSIST was equivalent to structures obtained in previous investigations with this inventory.

Factor analysis is used, among other purposes, to develop and validate scales in inventories, and to reduce the number of variables to be used in future analysis (McDermeit et al. 2000). In this sense, factor analysis allows to test the theoretical structure of an instrument and assure that the items are associated with the respective scales or subscales.

In the present study, exploratory factor analysis was used to determine the factor structure of data. Like other authors (Entwistle et al. 1979; Entwistle and Ramsden 1983; Diseth 2002; Long 2003), we used principal component axis method (PCA) to extract the 
factors as well as a non-orthogonal rotation procedure to facilitate the interpretation of the dimensions obtained.

The size of the present sample exceeds the minimum size requirements suggested by several authors for factor analysis (Guilford 1956; Gorsuch 1983; Bryant and Yarnold 1995; Tabachnick and Fidell 1996).

For the participants that have missing data items (less than $2 \%$ of the sample), the mean substitution procedure was used to replace missing values in a variable by the mean value for that variable. The data was analysed by means of SPSS 14.0 (SPSS Inc. 2006).

\section{Results and discussion}

Table 1 displays sample descriptive statistics for each scale and subscale, including mean, standard-deviation, skewness, and kurtosis. The skewness and kurtosis values ranged between-0.5 and 0.5, indicating only small departures from normality (Maroco 2003; Pestana and Gageiro 2003). However, some of them are statistically different from 0 $(P<.05)$, suggesting that scores distributions are negatively skewed for some Deep and Strategic subscales (revealing a larger concentration of answers on the higher levels of the scales, and greater dispersion on the lowest levels) and positively skewed for some Surface Apathetic subscales (score distributions reveal the inverse pattern).

Every investigation with psychometric instruments must demonstrate evidences of internal reliability of the measures collected (Duff 2001). We calculated one internal consistency coefficient for each scale and subscale (Cronbach's alpha) and compared our results with other investigations developed in different countries. The first column of Table 2 presents alpha coefficients obtained for the ASSIST Portuguese version.

The alpha values for the main scales range from 0.79 to 0.83 for the sample studied, indicating high levels of internal consistency (Nunnally 1978). The results for the subscales for our sample range from 0.40 to 0.73 .

Table 1 Descriptive statistics for ASSIST scales and subscales $(N=566)$

\begin{tabular}{llllr}
\hline Scales/subscales & Mean & SD & Skewness & Kustosis \\
\hline Deep approach & 15.48 & 1.58 & -0.30 & 0.66 \\
$\quad$ Seeking meaning & 15.81 & 1.97 & -0.38 & 0.43 \\
Relating ideas & 14.89 & 2.12 & -0.21 & 0.19 \\
Use of evidence & 15.99 & 1.83 & -0.23 & 0.60 \\
Interest in ideas & 15.26 & 2.18 & -0.47 & 0.30 \\
Surface apathetic approach & 12.22 & 2.11 & 0.21 & -0.18 \\
Lack of purpose & 10.12 & 3.48 & 0.34 & -0.37 \\
Unrelated memorising & 10.98 & 2.74 & 0.16 & -0.23 \\
Syllabus boundness & 12.66 & 2.84 & 0.12 & -0.32 \\
Fear of failure & 15.11 & 2.72 & -0.58 & 0.31 \\
Strategic approach & 14.30 & 1.86 & -0.17 & 0.03 \\
Organised study & 13.30 & 2.63 & -0.27 & -0.21 \\
Time management & 13.51 & 2.92 & -0.29 & -0.02 \\
Alertness to assessment demands & 14.16 & 2.31 & -0.18 & -0.09 \\
Achieving & 14.37 & 2.54 & -0.46 & 0.87 \\
Monitoring effectiveness & 16.13 & 2.13 & -0.60 & 0.83 \\
\hline
\end{tabular}


Table 2 Cronbach's Alpha coefficients $(\alpha)$

\begin{tabular}{|c|c|c|c|c|c|c|}
\hline & $\begin{array}{l}\text { Portugal } \\
(N=566)\end{array}$ & $\begin{array}{l}\text { USA } \\
(N=298)^{\mathrm{a}}\end{array}$ & $\begin{array}{l}\text { Ireland } \\
(N=437)^{\mathrm{b}}\end{array}$ & $\begin{array}{l}\text { Norway } \\
(N=573)^{\mathrm{c}}\end{array}$ & $\begin{array}{l}\text { Canada } \\
(N=1,080)^{\mathrm{d}}\end{array}$ & $\begin{array}{l}\mathrm{UK} \\
(N=817)^{\mathrm{e}}\end{array}$ \\
\hline Deep approach & 0.81 & 0.82 & 0.84 & 0.81 & - & 0.84 \\
\hline Seeking meaning & 0.51 & 0.55 & 0.63 & 0.49 & 0.62 & 0.57 \\
\hline Relating ideas & 0.54 & 0.59 & 0.59 & 0.62 & 0.59 & 0.59 \\
\hline Use of evidence & 0.59 & 0.49 & 0.59 & 0.49 & 0.51 & 0.53 \\
\hline Interest in ideas & 0.56 & 0.67 & 0.69 & 0.64 & 0.73 & 0.76 \\
\hline $\begin{array}{l}\text { Surface apathetic } \\
\text { approach }\end{array}$ & 0.79 & 0.80 & 0.83 & 0.70 & - & 0.87 \\
\hline Lack of purpose & 0.54 & 0.57 & 0.59 & 0.68 & 0.60 & 0.57 \\
\hline $\begin{array}{l}\text { Unrelated } \\
\text { memorising }\end{array}$ & 0.73 & 0.68 & 0.75 & 0.57 & 0.72 & 0.76 \\
\hline Syllabus boundness & 0.62 & 0.55 & 0.64 & 0.57 & 0.59 & 0.55 \\
\hline Fear of failure & 0.63 & 0.72 & 0.74 & 0.57 & 0.75 & 0.69 \\
\hline Strategic approach & 0.83 & 0.87 & 0.87 & 0.81 & - & 0.80 \\
\hline Organised study & 0.51 & 0.55 & 0.63 & 0.59 & 0.59 & 0.54 \\
\hline Time management & 0.65 & 0.77 & 0.74 & 0.72 & 0.80 & 0.68 \\
\hline $\begin{array}{l}\text { Alertness to } \\
\text { assessment demands }\end{array}$ & 0.40 & 0.56 & 0.63 & 0.41 & 0.62 & 0.76 \\
\hline Achieving & 0.67 & 0.63 & 0.68 & 0.66 & 0.67 & - \\
\hline $\begin{array}{l}\text { Monitoring } \\
\text { effectiveness }\end{array}$ & 0.58 & 0.61 & 0.61 & 0.51 & 0.60 & 0.62 \\
\hline
\end{tabular}

\footnotetext{
${ }^{a}$ Byrne et al. (2004b)

${ }^{\mathrm{b}}$ Byrne et al. (2004b)

${ }^{c}$ Diseth (2001)

${ }^{\mathrm{d}}$ Kreber (2003)

e Entwistle et al. (2001)
}

Although alpha coefficients for some scales were small (0.40), perhaps because each subscale comprise only four items, when we deal with psychological constructs values lower than traditional criteria (alpha < .70) can be expected (Kline 1994). In addition, our results are not different from those obtained in other validation studies (Byrne et al. 1999, 2004a; Entwistle et al. 2000; Diseth 2001; Tait et al. 1998). In summary, the alpha values for the main scales and subscales are acceptable for scales of this length and type (Byrne et al. 2004a; Entwistle et al. 2000) and are similar to the scores reported in other studies with the inventory (Byrne et al. 1999; 2004a; Tait et al. 1998; Entwistle et al. 2000; Diseth 2001).

In order to evaluate the factorial structure behind Portuguese sample responses to ASSIST, an exploratory factor analysis was performed. The choice of an exploratory approach was based on the fact that previous studies on ASSIST factorial structure have included such analyses in a preliminary phase. Kreber (2003) alerts that when the 52 items are factor-analysed the solution of 13 factors suggested by Tait et al. (1998) is not confirmed and the author recommended the analysis on a subscale basis. In consonance, we proceed with a factor analysis for the subscales - a procedure similar to the one adopted by Byrne et al. (2004b), Diseth (2001), Entwistle et al. (2000), Kreber (2003), and Tait et al. (1998). 
Table 3 Cronbach's Alpha, item-total correlations and average by scale

\begin{tabular}{llll}
\hline Scales & $\alpha$ & Item-total correlation (range) & Item-total correlation (average) \\
\hline Deep approach & 0.81 & $0.21-0.54$ & 0.45 \\
Surface apathetic approach & 0.79 & $0.18-0.55$ & 0.43 \\
Strategic approach & 0.83 & $0.13-0.58$ & 0.44 \\
\hline
\end{tabular}

Before factorial analysis, we performed a preliminary item-subscale correlation analysis in order to evaluate subscales validity. In general, results show that items theoretically associated with a subscale correlate strongly with this subscale than with the other subscales. Items-subscale correlations were significant, ranging between 0.13 e 0.58 . A few item-subscale correlations were small (lower than 0.30), suggesting eventually homogeneity problems. Nevertheless, these items always correlate higher with their subscales. Cronbach's alpha for subscales were satisfactory, ranging between 0.40 (alertness to assessment demands) and 0.73 (unrelated memorising). Globally, these results indicate that the 13 subscales of the inventory seem to provide valid and reliable measures. In consequence, we proceeded with the factorial analysis for subscales. Table 3 refers to item-total correlations by scale.

The analysis of the correlation matrix for subscales confirms the existence of an acceptable number of correlation coefficients higher than 0.30. Bartlett test value was significant $(P<0.000)$, indicating that this matrix is, in fact, different than an identity matrix (Field 2000). This result, with Kaiser-Meyer-Olkin value (1960 cit. in Zwick and Velicer 1986$)-\mathrm{KMO}=0.834)$, classified as very good according to Hutcheson and Sofroniou (1999)—confirms the factorability of the data.

Data were factorised using PCA method. To determine the number of components to be retained, we used Kaiser classic criterion and also the scree plot (Cattell 1966 cit. in Zwick and Velicer 1986) graphical representation (Fig. 1).

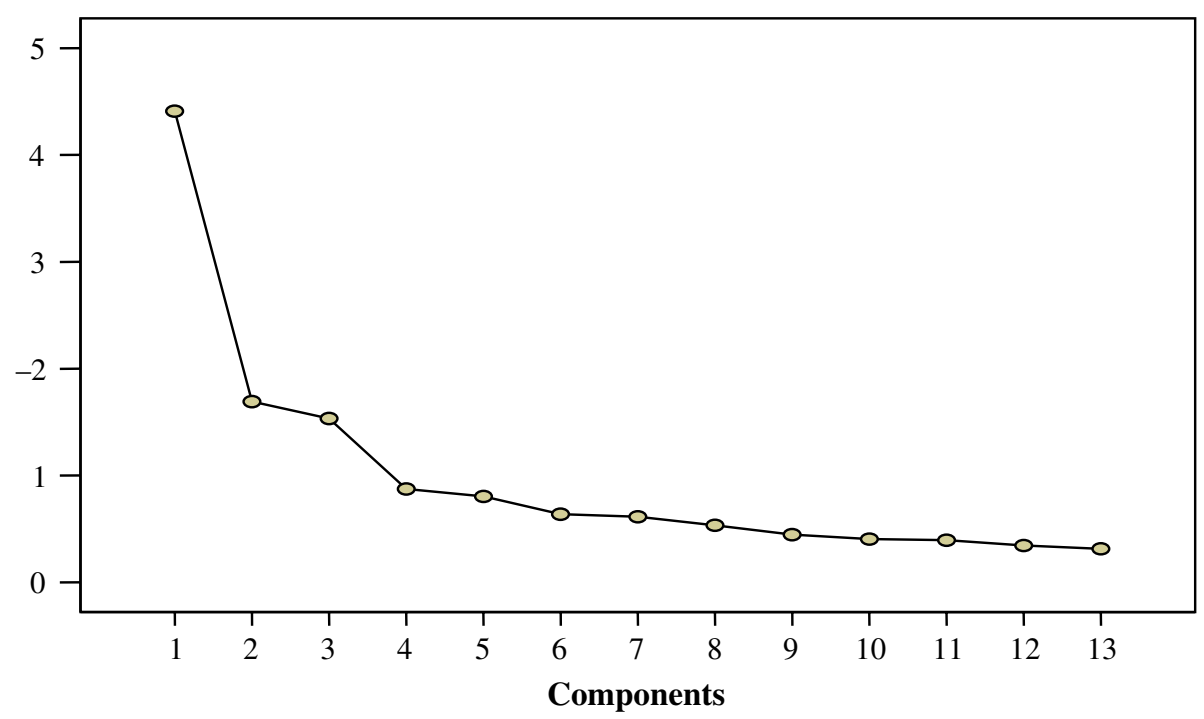

Fig. 1 Scree plot 
Scree plot analysis reveals a clear inflexion after the third component. This result supports the factor structure of three components with eigenvalues $>1$.

The next step in the analysis was the rotation of the three factors extracted. According to Duff (1997), and considering the theoretical dependence between the ASSIST three factors (Diseth 2001; Entwistle et al. 2000), a non-orthogonal rotation seems to be the correct option to this inventory. The extracted factor matrix was rotated to oblique simple structure using a direct oblimin rotation. This rotation procedure allows the factors to correlate (or not).

The solution obtained explains approximately 59\% of total variance, with the contribution of $33.9 \%$ from Factor I, of $13.0 \%$ from Factor II and of $11.7 \%$ from Factor III. This appears to be the most appropriated solution in terms of equilibrium between interpretability and the percentage of variance explained. Table 4 illustrates the results obtained.

The three factors obtained after rotation are those theoretically expected and can be clearly identified as Deep (Factor I), Surface Apathetic (Factor II), and Strategic (Factor III). Several authors recommend that only items with saturation higher than 0.30 should be considered in the factor interpretation (Kline 1994; Loewenthal 2001; Nunnally 1978). Entwistle et al. (2000) adopted this criterion in their studies with ASSIST and we also adopted this criterion in our study. As in other investigations with the inventory (Byrne et al. 1999, 2004a; Diseth 2001), we observed that two subscales (alertness to assessment demands and monitoring effectiveness) load simultaneously in two different factors.

Table 4 Correlations between factors and subscales, and communalities $(N=566)$
Notes extraction method: principal components axis. Rotation: Direct Oblimin with Kaiser normalization

\begin{tabular}{|c|c|c|c|}
\hline \multirow[t]{2}{*}{ Subscales } & \multicolumn{3}{|c|}{ Correlations } \\
\hline & F I & F II & F III \\
\hline \multicolumn{4}{|l|}{ Deep approach } \\
\hline Seeking meaning & 0.79 & 0.04 & -0.03 \\
\hline Relating ideas & 0.79 & -0.03 & -0.05 \\
\hline Use of evidence & 0.78 & -0.01 & 0.12 \\
\hline Interest in ideas & 0.68 & -0.10 & -0.01 \\
\hline \multicolumn{4}{|l|}{ Surface apathetic approach } \\
\hline Lack of purpose & -0.05 & 0.62 & 0.23 \\
\hline Unrelated memorising & -0.24 & 0.78 & 0.05 \\
\hline Syllabus boundness & -0.25 & 0.58 & -0.12 \\
\hline Fear of failure & 0.19 & 0.69 & 0.03 \\
\hline \multicolumn{4}{|l|}{ Strategic approach } \\
\hline Organised study & -0.10 & -0.04 & 0.84 \\
\hline Time management & -0.09 & -0.08 & 0.85 \\
\hline Alertness to assessment demands & 0.18 & 0.31 & 0.53 \\
\hline Achieving & 0.03 & -0.17 & 0.76 \\
\hline Monitoring effectiveness & 0.35 & -0.01 & 0.51 \\
\hline \multicolumn{4}{|l|}{ Correlations between factors } \\
\hline Factor I & 1.00 & -0.13 & 0.37 \\
\hline Factor II & -0.13 & 1.00 & -0.16 \\
\hline Factor III & 0.37 & -0.16 & 1.00 \\
\hline
\end{tabular}


A positive correlation between Factor I (Deep Approach) and Factor III (Strategic Approach) was observed, indicating that these components are not totally independent $(r=.37)$. The investigation on approaches to learning revealed that Deep and Surface Apathetic approaches are quite independent or can correlate negatively; in the contrary, a positive significant correlation is frequently observed between Deep and Strategic approaches. According to Entwistle et al. (2000), we can expect a positive moderate correlation between deep and strategic factors, and a negative correlation between deep and surface apathetic approaches, and also between surface apathetic and strategic approaches. A similar pattern of results was observed in the present investigation, confirming the authors' assumptions.

\section{Discussion}

Although some authors (e.g. Entwistle and Waterson 1988; Harper and Kember 1989; Meyer and Parsons 1989; Richardson 1994a, b; Speth and Brown 1988) referred to difficulties in reproducing the original structure of the ASI which suggested limited construct validity, the present investigation has identified a factorial structure with three components that is consistent with the original research, as well as with additional studies (Byrne et al. 2002, 2004a, b; Diseth 2001, 2002; Entwistle et al. 2000; Kreber 2003; Long 2003; Tait et al. 1998).

It was our purpose to develop a Portuguese version of the ASSIST, taking into account the fact that this is an adaptation to a population with different characteristics from the original (English college students). With respect to the transculturality, Richardson (1995) alerts for the existence of qualitative differences when we are assessing study motivations in diverse academic contexts. To the author, approaches to study must be understood culturally and we must be cautious when we use instruments of this nature in non western cultures.

For our sample, the resulting three factors were those that were expected conceptually and can be identified as deep, surface and strategic, as shown in the pattern matrix. Nevertheless, some subscales did not load as expected and there are some limitations that must be identified.

Another aspect to be considered is related to what the ASSIST measures. According to Byrne et al. (2004a, b) the ASSIST measures the broad learning approaches of a group of students, but it seems to fail to fully examine the complexity of individualised ways of learning and studying. In this sense, to explore the individual richness of student learning, we suggest the combination of qualitative and quantitative research. For instance, if we examine the variables that influence the process of learning in terms of the $3 \mathrm{P}$ model of presage, process and product, as proposed by Biggs (1993), we have to consider how the variables that apparently determine learning behave along a period of time. Systemic approach as defended by Biggs and Entwistle is a way of studying the phenomena, but according to the phenomenographic approach initially used by Marton and his colleagues, it is important to emphasize qualitative different ways of perceiving experience, learning and perceptions not only of the students, but also of the teachers. The nature of understanding learning phenomena, the way students transfer knowledge and the structures and 
competencies they use, as well as knowledge monitoring, are important issues that can be addressed in future investigations. In our opinion it is possible and desirable the combination of the two approaches and some authors even propose the use of the inventory along with other measures of the learning process (for instance, the Course Experience Questionnaire along with case stories methodology. Though our analysis focused mainly on group level, future investigations can address individual aspects of the teaching and learning process.

Although it was not our purpose to generalise this results to other contexts, the use of other samples, from other universities, may be useful to observe variation in students.

Even though we did test the inventory on 566 students, our sample is not representative of all the students at the university, as we have showed before. This result can be related to the fact that access to all students was not possible, and participants were those who attended classes.

Also, some subscales need further examination, considering that they did not behave exactly as expected. The inventory appears to be valuable as a research tool for the assessment of approaches to learning among Portuguese college students, but cautions should be taken with respect to the interpretation of particular subscales and possible sample effects.

Nevertheless, in our sample, the students seem to demonstrate the underlying constructs of the three distinctive approaches to learning.

The purpose of this study was to validate the ASSIST for use with higher education students in first and final years of study, from different academic subjects. Factor analysis was conducted on data gathered from a sample of students in Portugal. The resulting factor patterns clearly identified the expected deep, surface apathetic and strategic approaches to learning. Accordingly, the ASSIST seems to be an instrument that will yield valid and reliable scores for assessing the learning approaches of students from different courses and years. The ASSIST can be useful as an instrument of diagnosis of the approaches to learning in Portuguese higher education students.

These findings offer higher education students and teachers information concerning predominant approaches to learning and the design and construction of individual learning environments. Teachers and students can evaluate how students perform in different subjects and learning tasks, and they can also monitor changes in students' approaches over time. In this sense, teachers can consider ways of appropriately aligning the curriculum, teaching and assessment strategies, ultimately leading to the design of initiatives focused on improving learning approaches and outcomes.

Additionally, this study might initiate a dialogue between teachers and students regarding their expectations and responsibility in terms of tutorial support and educational strategies needed in the recent context of the Bologna process.

Acknowledgments The authors are obliged to Professor John Richardson (The Open University, UK) for language and content revision to Ida Lemos for helpful remarks on previous versions of this article. This research was supported by Acção 5.3 Formação Avançada de Docentes no Ensino Superior, Concurso 2/ 5.3PRODEP/2003 and Projecto S.P.A.S.H.E (POCTI/CED/42716/2001). 


\section{Appendix}

\section{A S S IS T \\ Approaches and Study Skills Inventory for Students}

Autores: Entwistle, Tait \& McCune (1999)

Tradução e adaptação: Valadas, Ribeiro Gonçalves e Cabral (2005)

Instruções

Este questionário foi concebido para descrever, de forma sistemática, o modo como estuda e aprende. São-lhe apresentadas uma série de afirmações, que em parte se sobrepõem entre si, de modo a abarcar as diferentes formas de estudo. A maior parte dos itens é baseada em afirmações e comentários realizados por estudantes em investigações anteriores.

Pedimos-lhe que responda com sinceridade, para que as suas respostas reflictam exactamente o seu pensamento actual sobre o modo como realmente estuda. Preencha o questionário respondendo rapidamente a cada questão (deverá assinalar sempre com um círculo em torno da alternativa que melhor descreve a sua opinião).

Muito obrigada pela sua colaboração.

\section{A. 0 que é a aprendizagem?}

\section{Quando pensa no termo 'APRENDIZAGEM ', qual o significado que tem para si?}

Leia atentamente cada uma das afirmações seguintes e classifique-as em função do grau de proximidade à sua própria forma de pensar sobre a "aprendizagem".

\section{5= Muito próximo; 4= Bastante próximo; 3= Não muito próximo; 2= Bastante diferente; $1=$ Muito diferente}

a. Assegurar que me lembro bem das coisas que aprendo.

b. Contribuir para o meu desenvolvimento pessoal.

c. Aumentar o meu conhecimento através da obtenção de factos e informação.

d. Ser capaz de utilizar a informação adquirida.

e. Compreender material novo por mim mesmo(a).

f. Adquirir uma visão nova e mais significativa das coisas.
543321

544321

544321

543321

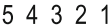

$5 \quad 43321$

\section{B. Abordagens ao estudo:}

Nesta secção do questionário é-lhe pedido que indique o seu grau de acordo ou desacordo com algumas afirmações feitas por estudantes sobre o estudo. Leia as frases e escreva a sua resposta imediata. Pense em função do curso que frequenta. Não se esqueça de responder a todas as questões, tendo em conta a seguinte escala:

$C T=$ concordo totalmente; $C=$ concordo; $C D=$ não concordo nem discordo; $D=$ discordo; $D T=$ discordo totalmente

1. Consigo arranjar condições para estudar que me permitem fazer o meu trabalho sem problemas.... CT C CD D DT

2. Quando estou a realizar um trabalho para uma cadeira, tenho presente qual a melhor maneira de impressionar o professor que o vai avaliar.

CT C CD D DT

3. Muitas vezes, questiono-me se o trabalho que estou a fazer neste curso vale realmente a pena. ..... CT C CD D DT

4. Geralmente tento perceber por mim próprio(a) o significado do que tenho de aprender.

CT C CD D DT

5. Organizo com cuidado o meu tempo de estudo de forma a aproveitá-lo ao máximo.

CT C CD D DT

6. Acabo por me concentrar apenas em memorizar uma grande parte daquilo que tenho de aprender. CT C CD D DT

7. Revejo com cuidado o trabalho que fiz para verificar a argumentação e para me certificar que faz sentido. 
8. Muitas vezes sinto que me estou a afundar perante a enorme quantidade de material/informação com que tenho de lidar.

9. Analiso com cuidado os dados e tento chegar às minhas próprias conclusões sobre a matéria que estou a estudar

10. É importante para mim sentir que estou a dar o meu melhor nas disciplinas que frequento.

11. Sempre que possível, tento relacionar ideias que me surgem com ideias relativas a outros tópicos e a outras disciplinas.

12. Tenho tendência para ler muito pouco além do que é necessário para passar às disciplinas.

13. Regularmente, quando estou a fazer outras coisas, dou por mim a pensar em ideias que surgiram nas aulas

14. Penso que sou bastante sistemático(a) e organizado(a) quando tenho de estudar para os exames.

15. Ouço atentamente os comentários dos professores sobre os trabalhos que fiz para a disciplina, para ver como conseguir melhores resultados da próxima vez.

16. Acho que a maioria do trabalho que faço no curso é pouco interessante ou irrelevante.

17. Quando leio um artigo ou livro, tento descobrir por mim o que o autor está exactamente a querer dizer.

18. Não tenho qualquer dificuldade em estudar ou em fazer um trabalho quando isso é mesmo necessário.

CT C CD D DT

19. Grande parte do que estou a estudar não faz muito sentido: é como se fossem peças e bocados que não se relacionam entre si.

20. Costumo ter presente o que quero conseguir com este curso para melhor orientar o meu estudo. .

CT C CD D DT

21. Quando estou a estudar um novo tópico, tento visualizar na minha mente a forma como todas as ideias se relacionam entre si.

CT C CD D DT

22 Preocupo-me muitas vezes se serei capaz de gerir adequadamente o trabalho que tenho de fazer. CT C CD D DT

23. Muitas vezes, dou por mim a questionar coisas que ouvi nas aulas ou que li em livros.

CT C CD D DT

24. Sinto que estou a progredir bem, e isso ajuda-me a investir mais no estudo.

CT C CD D DT

25. Concentro-me em apenas aprender a informação que tenho de saber para passar.

CT C CD D DT

26. Penso que estudar tópicos académicos pode ser às vezes bastante estimulante.

CT C CD D DT

27. Não tenho dificuldades em seguir alguma da bibliografia sugerida pelos professores.

CT C CD D DT

28. Tenho em conta quem vai corrigir o exame e o tipo de coisas que poderá estar à procura.

CT C CD D DT

29. Quando olho para trás, muitas vezes questiono-me porque é que decidi vir para este curso.

CT C CD D DT

30. Quando estou a ler, faço uma pausa de vez em quando, para reflectir sobre o que estou a tentar aprender a partir dessa leitura.

CT C CD D DT 
32. Não sei bem o que é realmente importante nas aulas, por isso tento tirar o máximo possível de apontamentos.

33. As ideias que leio nos livros ou em artigos estimulam muitas vezes uma longa série de pensamentos meus.

34. Antes de começar a escrever um trabalho ou a responder a uma pergunta de um exame, penso primeiro qual a melhor forma de o/a abordar.

35. Acontece-me muitas vezes entrar numa espécie de pânico quando sinto que estou a ficar para trás em relação ao trabalho que tenho de fazer.

36. Quando leio, examino com cuidado os pormenores para ver se estão de acordo com a ideia geral que está a ser desenvolvida.

37. Invisto bastante no estudo porque estou determinado(a) a obter bons resultados.

38. Organizo o meu estudo de forma a ter de estudar apenas o que parece ser exigido para os trabalhos e para os exames.

39. Acho alguns dos assuntos com que me deparo no curso extremamente interessantes.

40. Geralmente planeio com antecedência o meu estudo durante a semana, quer em papel quer mentalmente.

41. Tento estar atento(a) ao que os professores parecem pensar que é o importante e concentro-me nisso.

42. Não estou realmente interessado(a) neste curso, mas tenho de o concluir por outras razões.

43. Antes de começar a tentar resolver um problema ou a fazer um trabalho, tento primeiro perceber qual é a lógica por trás disso.

CT C CD D DT

44. Geralmente utilizo bem o meu tempo durante o dia

CT C CD D DT

45. Tenho muitas vezes dificuldade em compreender o significado das coisas que tenho de me lembrar.

CT C CD D DT

46. Gosto de trabalhar com ideias minhas, mesmo que isso não me leve muito longe.

47. Quando acabo um trabalho, verifico-o para ver se responde realmente ao que foi pedido.

48. Muitas vezes fico acordado(a) a preocupar-me com o estudo e os trabalhos que penso que não serei capaz de fazer.

49. Para mim é importante conseguir seguir o raciocínio ou compreender a razão que está por detrás das coisas.

50. Não tenho nenhuma dificuldade em motivar-me

51. Gosto que me digam exactamente o que tenho de fazer nos trabalhos que me pedem. 
C. Preferências por diferentes tipos de aulas e formas de ensinar. Tendo em conta a escala $\mathbf{5}$ = gosto muito; $\mathbf{4}$ = gosto; $\mathbf{3}$ = não gosto nem desgosto; $\mathbf{2}$ = não gosto 1 = não gosto nada, assinale com um círculo em torno daquela que representa a sua opinião.

a. Professores que nos dizem exactamente o que escrever nos nossos apontamentos.

b. Professores que nos incentivam a pensar por nós próprios e que nos mostram a forma como eles próprios pensam.

c. Exames que me permitem mostrar que pensei sobre o material da disciplina

d. Exames ou testes para os quais são suficientes os apontamentos das aulas.

e. Disciplinas onde é explicitado de forma clara quais os livros que temos de ler.

f. Disciplinas onde somos encorajados a ler muito sobre um assunto.

\section{Como pensa que tem sido, até agora, o seu aproveitamento no trabalho escolar já avaliado? Por favor avalie-se objectivamente, baseando-se nas notas que obteve até agora.}

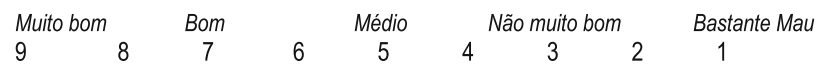

Certifique-se, por favor, que respondeu a todas as questões.

\section{References}

Almeida, L., \& Freire, T. (2000). Metodologia da Investigação em Psicologia e Educação. Braga: Psiquilíbrios.

Biggs, J. B. (1987a). Student approaches to learning and studying. Hawthorn, VIC: Australian Council for Educational Research.

Biggs, J. B. (1987b). Study process questionnaire. Melbourne: Australian Council for Educational Research.

Biggs, J. B. (1993). What do inventories of students' learning processes really measure? A theoretical review and clarification. The British Journal of Educational Psychology, 63(1), 3-19.

Biggs, J. B. (2001). Enhancing learning: A matter of style or approach? In R. Sternberg \& L.-F. Zhang (Eds.), Perspectives on thinking, learning, and cognitive styles (pp. 73-102). Mahwah, NJ: Lawrence Erlbaum Associates Inc., Publishers.

Bryant, F., \& Yarnold, P. (1995). Principal component analysis and exploratory and confirmatory factor analysis. In L. Grimm \& P. Yarnold (Eds.), Reading and understanding multivariate analysis (pp. 99136). Washington, DC: American Psychological Association Books.

Byrne, M., Flood, B., \& Willis, P. (1999). Approaches to learning: Irish students of accounting. Irish Accounting Review, 6(2), 1-29.

Byrne, M., Flood, B., \& Willis, P. (2002). The relationship between learning approaches and learning outcomes: A study of Irish accounting students. Accounting Education: an international journal, 11(1), $27-42$.

Byrne, M., Flood, B., \& Willis, P. (2004a). Validation of the Approaches and Study Skills Inventory for Students (ASSIST) using accounting students in the USA and Ireland: A research note. Accounting Education: an International Journal, 13(4), 449-459. 
Byrne, M., Flood, B., \& Willis, P. (2004b). Using the student learning framework to explore the variation in academic performance of European business students. Journal of Further and Higher Education, 28(1), 67-78. doi:10.1080/0309877032000161823.

Diseth, A. (2001). Validation of a Norwegian version of the Approaches and Study Skills Inventory for Students (ASSIST): an application of structural equation modelling. Scandinavian Journal of Educational Research, 45(4), 381-394. doi:10.1080/00313830120096789.

Diseth, A. (2002). The relationship between Intelligence, approaches to learning and academic achievement. Scandinavian Journal of Educational Research, 46(2), 219-230. doi:10.1080/00313830220142218.

Duff, A. (1997). A note on the reliability and validity of a 30-item version of Entwistle \& Tait's revised approaches to learning inventory. The British Journal of Educational Psychology, 67(4), 529-539.

Duff, A. (2001). A note on the psychometric properties of the learning styles questionnaire (LSQ). Accounting Education, 10(2), 185-197. doi:10.1080/09639280110095764.

Entwistle, N. J. (1979). Personal development and academic learning. A review and a postscript. Higher Education, 8, 487-490. doi:10.1007/BF01680538.

Entwistle, N. J. (1997a). Reconstituting approaches to learning: A response to Webb. Higher Education, 33, 213-218. doi:10.1023/A:1002930608372.

Entwistle, N. J. (1997b). Contrasting perspectives on learning. In F. Marton, D. J. Hounsell, \& N. J. Entwistle (Eds.), The Experience of Learning (2nd ed.). Edinburgh: Scottish Academic Press.

Entwistle, N. J. (2000). Approaches to studying and levels of understanding: The influences of teaching and assessment. In J. C. Smart (Ed.), Higher education: Handbook of theory and research (Vol. 15, pp. 156-218). New York: Agathon Press.

Entwistle, N. J., \& Peterson, E. R. (2004). Conceptions of learning and knowledge in higher education: Relationships with study behaviour and influences of learning environments. International Journal of Educational Research, 41, 407-428. doi:10.1016/j.ijer.2005.08.009.

Entwistle, N. J., \& Ramsden, P. (1983). Understanding student learning. London: Croom Helm.

Entwistle, N. J., \& Tait, H. (1994). The revised approaches to studying inventory. Edinburgh: University of Edinburgh, Centre for Research into Learning and Instruction.

Entwistle, N. J., \& Waterson, S. (1988). Approaches to studying and levels of processing in university students. The British Journal of Educational Psychology, 58(3), 258-265.

Entwistle, N., Hanley, M., \& Hounsell, D. (1979). Identifying distinctive approaches to studying. Higher Education, 8, 365-380. doi:10.1007/BF01680525.

Entwistle, N. J., Tait, H., \& McCune, V. (2000). Patterns of response to an approaches to studying inventory across contrasting groups and contexts. European Journal of Psychology of Education, 15(1), 33-48.

Entwistle, N. J., McCune, V., \& Walker, P. (2001). Conceptions, styles and approaches within higher education; analytical abstractions and everyday experience. In R. Sternberg \& L.-F. Zhang (Eds.), Perspectives on thinking, learning, and cognitive styles (pp. 103-136). Mahwah, NJ: Lawrence Erlbaum Associates Inc., Publishers.

Field, A. (2000). Discovering statistics using SPSS (1st ed.). London: Sage Publications.

Gorsuch, R. L. (1983). Factor analysis. Hillsdale, NJ: Lawrence Erlbaum.

Guilford, J. P. (1956). Psychometric methods. New York: McGraw-Hill.

Harper, G., \& Kember, D. (1989). Interpretation if factor analyses from the approaches to studying inventory. The British Journal of Educational Psychology, 59, 66-74.

Hattie, J., Biggs, J., \& Purdie, N. (1996). Effects of learning skills interventions on student learning: A metaanalysis. Review of Educational Research, 66(2), 99-136.

Hill, M. M., \& Hill, A. (2000). Investigação por questionário. Edições Sílabo, Lda: Lisboa.

Hutcheson, G., \& Sofroniou, N. (1999). The multivariate social scientist: Introductory statistics using generalized linear models. Thousand Oaks, CA: Sage Publications.

Kline, P. (1994). An easy guide to factor analysis. London: Routledge.

Kreber, C. (2003). The scholarship of teaching: A comparison of conceptions held by experts and regular academic staff. Higher Education, 46, 93-121. doi:10.1023/A:1024416909866.

Loewenthal, K. M. (2001). An introduction to psychological tests and scales. Hove: Psychology Press Ltd.

Long, W. F. (2003). Dissonance detected by cluster analysis of responses to the approaches and study skills inventory for students. Studies in Higher Education, 28(1), 21-35. doi:10.1080/03075070309303.

Lonka, K., \& Lindblom-Ylänne, S. (1996). Epistemologies, conceptions of learning, and study practices in medicine and psychology. Higher Education, 31(1), 5-24. doi:10.1007/BF00129105.

Maroco, J. (2003). Análise Estatística com utilização do SPSS (2 $2^{\mathrm{a}}$ edição). Edições Sílabo, Lda: Lisboa.

Marton, F., \& Säljö, R. (1976a). On qualitative differences in learning, I-outcome and process. The British Journal of Educational Psychology, 46(1), 4-11.

Marton, F., \& Säljö, R. (1976b). On qualitative differences in learning, II-outcome as a function of the learner's conception of the task. The British Journal of Educational Psychology, 46(1), 115-127. 
Marton, F., \& Säljö, R. (1997). Approaches to learning. In F. Marton, D. J. Hounsell, \& N. J. Entwistle (Eds.), The experience of learning: Implications for teaching and studying in higher education (2nd ed., pp. 39-58). Edinburgh: Scottish Academic Press.

McCune, V. (1998). Academic development during the first year at university. In C. Rust (Ed.), Improving student learning: Improving students as learners (pp. 354-358). Oxford: Oxford Brookes University, Oxford Centre for Staff and Learning Development.

McDermeit, M., Funk, R., Foss, M., \& Dennis, M. (2000). Exploratory factor analysis with alpha method and varimax rotation. LI analysis training series. Bloomington: Chestnut Health Systems.

Meyer, J. H. F. (2001). An overview of the development and application of the reflections on learning inventory (RoLI). Paper presented at a symposium on the use of the RoLI, Kings' College, London.

Meyer, J. H. F., \& Parsons, P. (1989). An empirical study of English-and Afrikaansspeaking students' approaches to studying. South African Journal of Higher Education, 3, 109-114.

Nunnally, J. (1978). Psychometric theory (2nd ed.). New York: McGraw Hill.

Pestana, M. H., \& Gageiro, J. N. (2003). Análise de dados para Ciências Sociais: A complementaridade do SPSS ( $3^{\mathrm{a}}$ ed.). Edições Sílabo, Lda: Lisboa.

Pintrich, P. R., \& García, T. (1994). Self-regulated learning in college students: Knowledge, strategies, and motivation. In P. R. Pintrich, D. R. Brown, \& C. E. Weinstein (Eds.), Student motivation, cognition, and learning: Essays in honour of Wilberg J. McKeachie (pp. 113-133). Hillsdale, NJ: Erlbaum.

Ramsden, P. (1988). Improving learning: New perspectives. London: Kogan Page.

Ramsden, P., \& Entwistle, N. J. (1981). Effects of academic departments on students' approaches to studying. The British Journal of Educational Psychology, 51, 368-383.

Richardson, J. T. E. (1994a). Mature students in higher education: Academic performance and intellectual ability. Higher Education, 28(3), 373-386. doi:10.1007/BF01383723.

Richardson, J. T. E. (1994b). Mature students in higher education: 1. A literature survey on approaches to studying. Studies in Higher Education, 19(3), 309-325. doi:10.1080/03075079412331381900.

Richardson, J. T. E. (1995). Cultural specificity of approaches to studying in higher education: A comparative investigation using the approaches to studying inventory. Educational and Psychological Measurement, 55(2), 300-309. doi:10.1177/0013164495055002014.

Richardson, J. T. E. (2000). Researching student learning: Approaches to studying in campus-based and distance learning. Buckingham: SHRE and Open University Press.

Speth, C., \& Brown, R. (1988). Study approaches, processes and strategies: Are three perspectives better than one? The British Journal of Educational Psychology, 58(3), 247-257.

SPSS Inc. (2006). SPSS for windows release 14.0.2. Chicago: SPSS Inc.

Tabachnick, B. G., \& Fidell, L. S. (1996). Using multivariate statistics (3rd ed.). New York: Harper Collins.

Tait, H., \& Entwistle, N. J. (1996). Identifying students at risk through ineffective study strategies. Higher Education, 31, 97-116. doi:10.1007/BF00129109.

Tait, H., Entwistle, N. J., \& McCune, V. S. (1998). ASSIST: A reconceptualisation of the approaches to studying inventory. In C. Rust (Ed.), Improving student learning: Improving students as learners. Oxford: Oxford Brookes University, Oxford Centre for Staff and Learning Development.

Vermunt, J. (1998). The regulation of constructive learning processes. The British Journal of Educational Psychology, 68(2), 149-171.

Zwick, W. R., \& Velicer, W. F. (1986). Comparison of five rules for determining the number of components to retain. Psychological Bulletin, 3, 432-442. doi:10.1037/0033-2909.99.3.432. 